\title{
Points
}

\section{Deaths in the first 10 minutes}

Dr SIMON PARKINSON (East Birmingham Hospital, Bordesley Green East, Birmingham B9 5ST) writes: Dr Brian Lewis (4 June, p 1768) rightly suggests that teaching cardiopulmonary resuscitation in schools would be beneficial. It seems sensible to propose that all schoolchildren are correctly instructed in such techniques and in other first aid measures. Should not the BMA, representing doctors, push hard for this to be achieved. The general campaign to raise standards of public awareness of health, including the antismoking message and the use of seat belts, makes this seem a logical step to take. Indeed, many people are still ignorant about medical matters - perhaps compulsory basic "medical education" is what is needed?

\section{Spina bifida and anencephaly}

Professor J H ELwood (Department of Community Medicine, Queen's University of Belfast, Belfast BT12 6BJ) writes: Professor Ian Leck (28 May, p 1679) wonders how much of the recent substantial decline in the prevalence at birth of anencephalus and spina bifida might be due to prenatal screening programmes and terminations of affected pregnancies. In Northern Ireland for 1974-9 383 anencephalic births (stillbirths plus deaths during the first week) were registered and another 18 affected pregnancies were terminated. This reduced the prevalence at birth from an expected rate of 25.5 to an observed rate of 23.9 , indicating that the influence of selective abortion on the prevalence rate was of the order of $6 \%$.

Elwood JH, Scott MJ. Prevalence of anencephalus in the United Kingdom. Dev Med Child Neurol 1982; 24:394.

\section{Caring for the young disabled}

Mr A W Fowler (Bridgend General Hospital, Bridgend, Mid Glamorgan) writes: Dr T G Williams (4 June, $p$ 1820) makes a plea for a register of facilities available throughout the country for the young disabled. The Sunday Times Self Help Directory (obtainable from Granada Publishing, 36 Golden Square, London W1R $4 \mathrm{AH}$, price $£^{3.95)}$ goes a long way to fulfilling this need. It lists no fewer than 100 organisations and self help groups concerned with the disabled and 30 organisations which deal specifically with handicapped children.

\section{Alcohol abuse in female acute medical admissions}

Dr J P Watris (St James's University Hospital, Leeds LS9 7TF) writes: Dr R J Northcote and others (28 May, p 1702) suggest that one reason for the fall in female acute hospital admissions related to alcohol abuse is the increase in the proportion of elderly women. This conflicts with the epidemiological work of Edwards et al, ${ }^{1}$ which suggested that the age specific prevalence of alcoholism in women peaked in the over 70s. An alternative explanation to the findings of Dr Northcote and others might be that elderly women patients with alcohol problems were presenting to different parts of the services-for example, departments of geriatric medicine or psychiatry of old age-or indeed not presenting to medical services at all. ${ }^{2} 3$ When considering age as a factor in the presentation of disease it is also important to consider the different services available to old people and their use of these services if possibly erroneous conclusions are to be avoided.

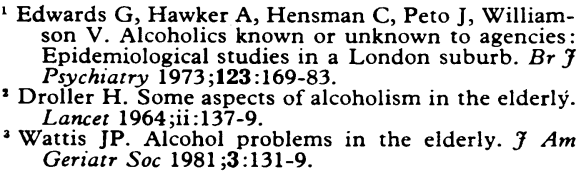
son V. Alcoholics known or unknown to agencies: Epidemiological studies in a London suburb. $B r f$ Psychiatry 1973;123:169-83.

2 Droller H. Some aspects of alcoholism in the elderlý. Lancet 1964; ii:137-9.

Wattis JP. Alcohol problems in the elderly. $f \mathrm{Am}$ Geriatr Soc 1981;3:131-9.

\section{Are genu genuflectorum and cleryman's knee the same thing?}

Dr W E GRIFFITHS (Plymouth General Hospital, Plymouth PL4 7LY) writes: Minerva (21 May, $p$ 1654) is unjust in her treatment of Dr T H Bracken, ${ }^{1}$ the discoverer of genu genuflectorum, whom she accuses of coining a superfluous term when clergyman's knee has long been recognised. ${ }^{1}$ The priest in question had an effusion of non-inflammatory fluid in his left knee, whereas in bursitis (clergyman's or housemaid's) the fluid naturally contains inflammatory cells.

While absolving the Americans in this case of unnecessary neologisation, I must admit that genuflection on the left knee is an unusual liturgical practice. My ecclesiastical adviser (a Benedictine monk and former naval officer) warns me that if one genuflects on the left knee while wearing a sword one will come a cropper. He also draws my attention to the earliest account of clergyman's knee by Hegesippus (second century) in his life of the apostle St James the Less: "His knees became hard like a camel's for he was continually bending the knee in worship to God."'2 ' Bracken TH. “Genu genuflectorum." N Engl f Med
$1983 ; 308: 1107$.
2 Thurston H, Attwater D, eds. Butler's lives of the
saints, vol II. London: Burns and Oates, 1956;205.

\section{Investigations for azoospermia}

Dr R F Mueller (Laboratory of Molecular Biology, Medical Research Council Centre, University Medical School, Cambridge CB2 $2 \mathrm{QH}$ ) writes: $\mathrm{Mr} \mathrm{J}$ C Gingell's suggestions of investigations for azoospermia (18 June, $p$ 1955) neglected to include obtaining a karyotype. In couples presenting to infertility clinics with high grade infertility-that is, azoospermia or a sperm count less than $1 \times 10^{6} / \mathrm{ml}$-one in five to one in nine men have Klinefelter's syndrome with the chromosomal complement $47, \mathrm{XXY}{ }^{1}$

Bergsma D, ed. Birth defects compendium. London Macmillan, 1977:613.

Leishman-Donovan bodies in a child with kala-azar

Dr R O PARNIs (Inverell, New South Wales) writes: The article on Leishman-Donovan bodies in the duodenal mucosa of a child with kala-azar (5 March, p 789) brought back memories of my younger son's infancy. In 1967 , at the height of the Nigerian civil war when Biafran troops were close to Ibadan, I prudently sent my family back to Malta. My son, then 15 months old, fell ill with fever, pallor, and boils some four to six weeks later, and in due course kala-azar was diagnosed. As the incubation period was so short it was assumed that the disease had been acquired in Nigeria, and I was contacted by wire regarding the drug of choice used at University College Hospital, Ibadan; kala-azar is resistant to antimony in the Sudan, and Nigerian kala-azar was possibly in the same category. I replied that the disease was unknown in Ibadan (I wonder if this statement is still correct), that the infection must have been picked up in Malta, and that pentavalent antimony compounds were therefore indicated. My son made a rapid recovery from a disease associated with sandflies and dogs and known in Malta as il-marda tal-bicca.

\section{Rifampicin and adrenal crisis}

Dr G Boss (Department of Thoracic Medicine, New Cross Hospital, London SE14 5ER) writes: Dr E H Elansary and Dr J E Earis (11 June, $p$ 1861) emphasise the hazards of giving rifampicin to patients with adrenal insufficiency. Hunter ${ }^{1}$ described a similar case in a paper given to the Royal College of Physicians in 1973, even before the paper of Edwards et al was published. ${ }^{2}$

Addison's disease due to tuberculosis is becoming less common. Much less rare, however, is the development of critical hypotension in non-Addisonian patients, occurring usually within a week or 10 days of starting rifampicin ${ }^{3}$; Edwards et al also described four such cases in their paper. ${ }^{2}$ These patients invariably have extensive, smear positive disease, and while clearly unwell on admission they became critically ill a few days after treatment with rifampicin has begun. Four hourly monitoring of blood pressure is essential in the first two weeks of rifampicin treatment. Intravenous hydrocortisone is started immediately hypotension develops and is usually followed by several weeks of treatment with oral steroids. These patients are not subsequently found to have an inadequate response to tetracosactrin (Synacthen).

It seems undesirable to suspend the use of rifampicin in these ill patients, and we have not found it necessary to do so.

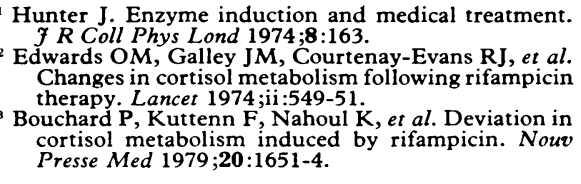
Presse Med 1979;20:1651-4.

\section{Correction}

New drugs: antiarrhythmic drugs

An error occurred in the letter by Dr H Yarrow (18 June, $\mathrm{p} 1980$ ). The third sentence should have read: "While the severity and frequency of the attacks [of paroxysmal atrial fibrillation] were somewhat ameliorated by drugs (in my case $100 \mathrm{mg}$ disopyramide four times a day), they always lasted several hours, sometimes a whole day." 